\title{
New Questions on the Battle of Khalkhin Gol (Nomonhan)
}

\author{
H iroak i Kuromiya ${ }^{1}$ (Japan)
}

\begin{abstract}
$\mathrm{H}$ istorians have argued almost unanimously that the Battle of Khalkhin Gol was initiated by the aggression of Imperial Japanese forces and that the outcome was a resounding victory for the Soviet Union.
\end{abstract} However, documents that have become available since the time of glasnost' and perestroika suggest the need for subtle yet significant modifications of this event. For instance, the Soviet/Mongol casualties turn out to be much larger than was acknowledged at the time. They in fact appear to be larger than those of the Japanese/Manchukuo forces. ${ }^{2}$

No fundamental reassessment has taken place for seventy-five years. Perhaps the only notable exception is Aleksei A. Kirichenko, a Russian specialist of Japan. Taking issue with his colleagues, Kirichenko claims that Japan did not start the short war: “This [Russian historians' claim about Japan's provocation of the Khalkhin Gol conflict] contradicts the simplest logic, because at that time Japan was, in the literal sense of the word, mired in the war in China and only the insane would have undertaken military actions against Soviet troops (even in Mongolia)" [Это противоречит простейшей логике, ибо в этот период Япония в буквальном смысле увязла в войне в Китае и затевать боевые действия с советскими войсками (пусть даже в Монголии) мог только сумасшедший. ${ }^{3}$ Yet, unfortunately, his work has been almost completely ignored in Russia.

One barrier to a clear understanding of the issues is that numerous relevant documents are still classified in Moscow's various archives. It is also likely that Tokyo still withholds relevant archival documents. Historians need unrestricted access to all archival documents. When examined, they may support established

1 Professor of History, Indiana University (USA) (hkuromiy@indiana.edu)

2 The Soviet casualties were 25,655 (of them 7,624 killed, 2,028 missing in action, 15,251 wounded). (Sеe Г. Ф. Кривошеев (ред.), Россия и СССР в войнах хх века: потери вооруженных сил. Статистическое исследование г [Москва: ОЛМА-ПРЕСС, 1993], p. 179.) Japan's casualties are 19,714 (8,717 killed, 8,647 wounded).

3 See, for example, А. А. Кириченко, “'Разборка' на Халхин-Голе,” Япония наших дней, 2014, no. 1 (19), p. 120. 
interpretations. They may not. I suggest that the latter is the case. In this essay I will deal with four issues related to the battle of Khalkhin Gol.

$$
* * *
$$

(1). The first issue concerns the commander of the Japanese main fighting force, the 23-rd Division, Lieutenant General Michitarō Komatsubara, who, as I have suggested in an earlier article, may have been a Soviet agent. He had been sexually compromised in Moscow in the 1920s when he was a Military Attachŭ and was probably blackmailed, as were some others in his situation. $\mathrm{He}$ likely betrayed his country and helped the Soviet forces in some as yet unknown way during the battle which he commanded on the Japanese side. This would explain many riddles of the battle, including the fact that his division suffered an inexplicably high casualty rate. ${ }^{4}$

If this is the case, the traditional interpretation, including the presumed responsibility for the breakout of the battle, would be turned on its head. The question of Komatsubara's possible treachery cannot be answered conclusively without access to classified documents in Moscow. Historians must demand open access to all relevant documents in Moscow. If Tokyo still withholds secret documents, these too must be de-classiified. Relevant documents on this particular matter are unlikely to exist in Ulaanbaatar, considering Stalin's views on matters of intelligence. In May 1937, Stalin told his secret police (NKVD) chief Nikolai Ezhov (Николай Ежов): "All allies are potential enemies, and they too have to be verified. From the point of view of intelligence, we cannot have $f$ riends: there are actual enemies and there are potential enemies. So we cannot reveal any secrets to anyone" [Все союзники возможные враги - и союзников тоже надо проверять. С точки зрения разведки у нас не может быть друзей, есть непосредтсвенные враги, есть враги возможные. / Поэтому никаких секретов никому не давать.]. Any actions by Komatsubara in the interest of Moscow would have been kept secret by Stalin from his Mongolian friends (who were in fact "potential enemies" from Stalin's point of view).

(2) Another puzzling question is the timing of the battle and Stalin's calculations. Nicholas Poppe, a famous Russian Mongolist, presents the following story of 1939 .

4 See, for example, А. А. Кириченко, “'Разборка' на Халхин-Голе,” Япония наших дней, 2014, no. 1 (19), p. 120.

5 Hiroaki Kuromiya, “The Mystery of Nomonhan, 1939," The Journal of Slavic Military Studies 24:4 (December 2011), pp. 659-77. On Komatsubara, Russian historian V. Datsyshen has recently published an essay: В. Дацышен, “' 'Миссия Комацубары.' Из истории советско-японско-китайских отношений в начале 1930-х годов,” Проблемы Дальнего Востока, 2012, nо. 3, pp. 126--133. Datsyshen does not question Komatsubara's real loyalty, however. 
Nineteen thirty-nine was an eventful year. In March or April I had the opportunity to prove the usefulness of Mongolian Studies to the Soviet government. One day I was asked to come to the office of the secretary of the Institute of Oriental Studies where I was introduced to a major-general named Bogdanov. He was the chief of the Soviet border commission whose task it was to delineate the frontier between Mongolia and Manchuria ... . General Bogdanov had come to ask for old Mongolian and Chinese maps on which borders were marked clearly. We showed him several Mongolian maps of Eastern Mongolia which he studied intently.

According to Poppe, Bogdanov (clearly, Mikhail A. Bogdanov [18981969] who as Chief of Staff of the First Army Group became the architect of the decisive offense successfully carried out in August 1939 at Khalkhin Gol $)^{6}$ was convinced by these maps that "the Japanese and Manchukuo claims were absolutely baseless." Is Poppe's recollection of March or April 1939 correct? If yes, it strongly suggests that Moscow made advance preparations for a military confrontation at Khalkhin Gol: the Battle of Khalkhin Gol started on 11 May 1939, shortly after Bogdanov, according to Poppe, examined historical maps of eastern Mongolia (where Khalkhin Gol is located).

It may be that Poppe was wrong about the timing of Bogdanov's visit, because he mentions the border commission (which was formed after the conclusion of the battle of Khalkhin Gol). Even so, it is very odd that Bogdanov's initial presentation at a meeting with the Japanese in Chita in early December 1939 appeared to the Japanese to be "hesitant and weak," was convinced that the Soviet demarcation of the border was absolutely correct. The battle of Khalkin Gol was followed immediately by the Molotov-Rippentrop Pact, the invasion of Poland by Germany and the Soviet Union, and a military attack on Finland by the Soviet Union. Poppe, who defected to the West during World War Two and then taught in the United States, remembers very well the tumultuous months of the autumn and winter of 1939 (when, incidentally, he fell gravely ill, then recovered and was asked by a Soviet military officer to translate a Finnish book deemed important to Soviet claims of Finnish territory). ${ }^{9}$ Therefore, it seems unlikely that Poppe would have confused the chronology of these events.

To further compound the situation, Bogdanov is said to have fallen to "Japanese provocation" in January 1940 in Harbin (where the border negotiations moved from Chita): he committed the "gravest error, and caused damage to the

6 Никита Петров и Марк Янсен, “Сталинскийй питомец” - Николай Ежов (Москва: РОССПЭН, 2008), p. 291.

7 Sеe Великая отечественная: Комдивы. Военный биографический словарь, т. 1 (Москва: Кучкове поле, 2011), стр. 348-351.

8 Nicholas Poppe, Reminiscences, ed. Henry G. Schwarz (Bellingham: Western Washington University Center for East Asian Studies, 1983), pp. 143-144 (emphasis added).

9 Alvin D. Coox, Nomonhan: Japan against Russia, 1939 (Stanford, Calif.: Stanford University Press, 1985), p. 982. 
prestige of the Soviet Union" (в результате провокации с японской стороны М. А. Богданов совершил грубейшую ошибку, нанесшую ущербу престижу CCCP). He was tried and sentenced to four years in the Gulag, but in August 1941 was amnestied with his convictions expunged and his decorations restored. ${ }^{10}$ This version of Bogdanov's conduct in Mongolia is rather dubious. ${ }^{11}$ Bogdanov has been almost completely expunged from Soviet history on the battle of Khalkhin Gol. What lies behind this strange story of Bogdanov and Khalkhin Gol? There is something important that remains unexplained. ${ }^{12}$ This question needs to be examined carefully.

(3) A defection that took place in 1938 may also make a contribution to the question of whether or not the Soviet-Mongol side provoked the battle of Khalkhin Gol. The defection of Genrikh S. Liushkov (Генрих С. Люшков), the head of NKVD in the Far East, to Manchukuo in June 1938 is well known. Much less known is the defection of "Captain" Khishigtiin Biambaa (Хишигтийн Бямбаa) to Manchukuo in August 1938. In fact, Biambaa was not even a captain or officer, but a rank-and-file soldier of the Mongolian Army. Biambaa's account is sensational: the Mongo lian People's Republic (MPR) was independent only on paper; it was completely controlled by the Soviets. The Soviet rule was such that the majority of the Mongolian people were ready to stand up against it. P. Genden, former Prime Minister, G. Demid, Defense Minister, and many other Mongolian leaders schemed against the Soviet rule, but were caught and executed. Yet four divisions of the Mongolian Army had already rebelled against the Soviet rule. 60 to 80 percent of the Mongolian people were ready to strike against the Soviets, believing that when they did, Japan would come to their aid. Biambaa defected to Manchukuo to enlist Japan in the fight of the Mongolians against the Soviet Union. ${ }^{13}$

Anyone familiar with Soviet and Mongolian history would know that this is typical Soviet provocation. Indeed, Biambaa's defection is full of odd details, and it is now confirmed that he was dispatched to Manchukuo as a military spy. ${ }^{14}$

${ }^{10}$ Ibid., pp. 144-145.

11 See Великая отечественная, стр. 350-351. For a more positive view of Bogdanov by Mongolian historians, see Ц. Батбаяр, Д. Гомбосүрэн, Монгол, Манжггогийн хилийн хэлэлиээ 1935-1941 он (Цэрэг-дипломатын түҮх) (Улаанбаатар: Алтан Үсэг, 2004), стр. 74-75.

${ }^{12}$ See my discussion in H-Diplo: http://h-diplo.org/essays/PDF/E111.pdf (6 June 2014) discussing Georgii K. Zhukov's memoir.

${ }^{13}$ Kirichenko writes that Bogdanov refused some of Zhukov's "risky orders" (авантюрные приказы) in Khalkhin Gol. As a result Zhukov accused Bogdanov of conspiring with the Japanese and supported his arrest. (Жуков обвинил Богданова [в] чуть ли не сговоре с японцами и поддержал его аррест.) Seе Кириченко, стр. 133-34.

${ }^{14}$ Biambaa's account was published in the Japanese press and in book form in 1939. It was translated into Mongolian in 1991: Японд зугтаж гарсан Бямба, Япон хэлнээс орчуулсан Д. Алмаас, найруулсан Л. Хуушаан (Улаанбаатар: Соёмбо, 1991). 
Indeed, during the battle of Khalkhin Gol, Biambaa was arrested, on the battle field, by the Japanese on suspicion of espionage for the enemy. He was tortured and was said to have killed himself after escaping from Japanese detention. (More likely he was tortured to death.) To hide this incident, it was announced to the public that Biambaa was killed in action during the battle of Khalkhin Gol. ${ }^{15}$

This Biambaa affair suggests that the Soviet-Mongol side was actually interested in provoking some kind of armed conflict with Japan at a time when Japan was preoccupied with its war in China. At the time Moscow rendered a great deal of human and material aid to China in an attempt to keep Japan mired in China. A skillfully executed conflict would then maximally weaken Japan's territorial and military ambitions towards Mongolia and the Soviet Far East and Siberia. In this light, it is not unreasonable, as Kirichenko suggests, that Japan may not have caused the Khalkhin Gol incident.

In any case, Mongolia and Russia should release all materials related to Biambaa.

(4) Another issue concerns Colonel Masanobu Tsuji and Marshall Georgii K. Zhukov. Tsuji was an exceedingly mysterious military man, who always took an aggressive line towards the Soviet Union. He was responsible for escalating the conflict in Khalkhin Gol in 1939. After Japan's defeat in 1945, Tsuji hid abroad for several years, then secretly returned to Japan. Subsequently elected to the Japanese parliament, Tsuji visited the Soviet Union in 1955 where, according to the CIA, he even met Zhukov secretly. ${ }^{16}$ Tsuji mysteriously disappeared in South East Asia in 1961.

What did Tsuji and Zhukov discuss in their secret meetings? Why did they meet secretly? It appears that it was Tsuji himself that let it be known to the CIA that he had met Zhukov in Moscow. Although Tsuji does not say whether he discussed the battle of Khalkhin Gol with Zhukov, it is unlikely that he did not. There must be some record on their meetings in Tokyo and Moscow. Such records would be of much interest to historians of the battle and may well shed new light on it.

\footnotetext{
${ }^{15}$ An account by Mongolian historian D. Khoroldamba (Д. Хоролдамба), as reported in Хироши Фүтаки, “Монголын Их Хэлмэгдүүлэлт ба Япон - 'оргодол' Бямбаагийн хувь заяаг ахин шинжлэх нь,” Д. Шүрхүү, Б. Сэржав (ред.), Монгол-японы харилияа: өнгөрсөн ба эдүгээ (хх зуун). Олон улсын эрдэм шинжилгээний хурал 2010.09.09 - 11. Улаанбаатар хот (Улаанбаатар: Бэмби Сан Хэвлэлийн Газар, 2011), тал. 75. I am grateful to Professor Futaki for providing a copy of this essay to me.

${ }^{16}$ See Mōko seinentō (zenmei jangyasuto dan) n kansuru kōsatsu (no place, 1940), pp. 2324 (available at Umemori Mongolian Library, Tokyo). I am grateful to Sada Umemori for providing a copy to me. See also Futaki, "Монголын Их Хэлмэгдүүлэлт ба Япон," тал. 75.
} 
$* * *$

Japan was an aggressive militaristic empire which waged warfare in the Pacific region from 1931 to 1945 . This does not mean that all conflicts were provoked by Japan. Japan's culpability is not diminished of course by the fact that the Soviet Union was equally aggressive. The propaganda that the Soviet Union was a "peace-loving" nation was simply a fiction. Under the cloak of the Comintern it engaged in subversion everywhere. It invaded China in 1929. In 1933-34 Moscow sent military forces under camouflage into Xinjiang, which it then turned into a virtual Soviet colony. Moscow made the Mongolian People's Republic, too, into a colony or satellite and in 1937-39 killed more than 20,000 Mongolians, many of whom were accused of being Japanese spies. Not a shred of evidence exists against any of them. Noteworthy is that Stalin's Great Terror killed proportio nately far more people in Mongolia than in the Soviet Union itself.

Immediately after the battle of Khalkhin Gol, the Soviet Union invaded Poland in collusion with Nazi Germany, followed by an invasion of Finland, starting the Winter War and grabbing part of Finnish territory. In 1944 Moscow annexed Tuva. In 1945, it violated the neutrality pact of 1941 with Japan and staged war against Japan. One needs to set the record straight.

In light of this recognition of two aggressive countries and in light of new historical sources that have become available in recent years, the established version of Japan's culpability for the battle of Khalkhin Gol appears not as certain as it once was. There simply are too many unresolved questions for us to be certain about Moscow's innocence. I have listed four issues here, the loyalty of Komatsubara, the issue of Bogdanov's activity before and after the battle, the significance of Biambaa's defection, and the mystery of The Tsuji-Zhukov meeting in 1955.

Moscow made every effort to mire Japan in a war against the Chinese so as to divert Japan's aggression away from the Soviet Union. The Marco Polo Incident of 7 July 1937 was a golden opportunity. Moscow therefore went to great lengths to assist the Chinese militarily, while rejecting China's request for the Soviet Union to join the war against Japan. In November 1937 Stalin quite frankly told the Chinese that China was strong enough not to be beaten by Japan. He added, however: "If Japan begins to triumph, the Soviet Union will enter into the war"! ${ }^{17}$ It turned out that there was no need for Stalin to enter into the war before 1945. Yet recognizing Japan's weakness and deeply concerned about the damage caused by Liushkov's defection, Moscow was tempted to test Japan in 1938. In

${ }^{17}$ U.S. National Archives \& Records Administration, RG 263, Second Release of Name Files, Tsuji Masanobu, 3 volumes, box 130, 230/86/24/5. 
1938 Moscow thus provoked the battle of Lake Khasan. ${ }^{18}$ Khalkhin Gol should be placed in this larger context.

One sees certain unspoken collusion in this respect. Moscow withholds vital archival documents related to Khalkhin Gol. Moscow's position is convenient to Tokyo, because the classified documents in Moscow are likely to expose numerous embarrassments concerning Tokyo's political ineptitude. Mongolia itself has been and still is largely eclipsed by the two aggressive countries that fought in Khalkhin Gol.

${ }^{18}$ Советско-китайские отношения в хх веке, том 4, книга 1 (Москва: Памятники исторической мысли, 2000), стр. 156. 